Www.jmscr.igmpublication.org

Impact Factor (SJIF): 6.379

Index Copernicus Value: 79.54

ISSN (e)-2347-176x ISSN (p) 2455-0450

crossrefDOI: https://dx.doi.org/10.18535/jmscr/v7i1.50

IGM Publication

Journal Of Medical Science And Clinical Research

An official Publication of IGM Publication

\title{
Effect of Intravenous Tranexamic Acid on Perioperative Blood Loss in Orthognathic Surgery
}

\author{
Authors \\ Dr Raveendra U.S $\mathbf{1}^{1}$, Dr Shameer $\mathbf{P}^{1 *}$ \\ ${ }^{1}$ Department of Anaesthesiology, K.S. Hegde Medical Academy, Mangalore, Karnataka, India \\ *Corresponding Author \\ Dr Shameer P
}

Post Graduate, Department of Anaesthesiology K.S. Hegde Medical Academy, Mangalore, Karnataka, India Phone (or Mobile) No: 9846888899, Email: shameerneo2000@ gmail.com

\begin{abstract}
Background: Orthognathic surgery is performed for the correction of dentofacial deformities which can result in significant bleeding from both incised soft tissues as well as bones, during the procedure and postoperatively due to the high vascularity of the maxillofacial region. Tranexamic acid (TA) is a drug with anti-fibrinolytic activity which helps in reducing the blood loss.

Aims: The main objective of the study is to evaluate the effect of intravenous TA on perioperative blood loss during orthognathic surgery in adult patients. Also the study is to assess the blood loss during surgery and the changes in hemoglobin and hematocrit in the both groups before and after surgery.

Settings and Design: prospective, randomized, double blind, control study

Methods and Material: ASA-I and ASA-II patients, between age 18 - 45 years, undergoing orthognathic surgery were divided in to two groups. Group A received TA $20 \mathrm{mg} / \mathrm{kg}$ over 20 minutes in $100 \mathrm{ml}$ normal saline 15 minutes before incision and Group B received equal amount of normal saline comprised a total of 52 patients in each group. Clinical parameters like counting the number of mops, gauzes and weighing them, blood in the suction, perioperative hemoglobin and hematocrit will be assessed.

Statistical analysis used: Collected data was analyzed by both descriptive and inferential statistical methods. Data was summarized by frequency percentage mean and standard deviation. To compare between two groups with respective and various quantitative parameters independent test was used. To compare between groups for categorical data chi-square and Fisher exact test calculator was used.

Results: The study was carried out in total of 104 patients, out of which 52 patients received TA and 52 patients received placebo. In the study there was a decrease in mean duration of surgery, decreased blood loss during surgery, decreased reduction of hemoglobin and hematocrit in study group when compared with control group, which was statistically significant.

Conclusions: The present study concluded that TA significantly reduced perioperative blood loss and transfusion requirements during orthognathic surgery.

Keywords: Tranexamic acid - TA, AMCA -Amino Caproic Acid, EACA - Epsilon-amino caproic acid, Hb-Hemoglobin, Hct - Hematocrit.
\end{abstract}

\section{Introduction}

Orthognathic surgery is the surgical correction of oral and facial deformities involving bones and soft tissues. This can result in significant bleeding from both incised soft tissues and bones during the procedure and rarely in postoperative period 
due to the rich blood supply and also because most of the vessels traversing the bones cannot be identified and isolated before or after osteotomies of mandible and/ or maxillary bones.

In addition, significant bleeding may occur during maxillary osteotomies from damage to the descending palatine artery, sphenopalatine artery, pterygoid venous plexus or occasionally from damage to the second part of the maxillary artery. Bleeding can also occur during mandibular osteotomies from damage to the mesenteric artery and vein, pterygoid venous plexus, or occasionally from damage to the facial artery. ${ }^{1,2,3}$

Le Forte I osteotomy with its modifications is the most common surgical technique performed for the correction of dentofacial deformities, others procedures being anterior maxillary osteotomy, bilateral sagittal split osteotomy and genitoplasty. Major blood supply of these are descending palatine arteries and inferior alveolar arteries being major source of bleeding. ${ }^{4}$

During the surgical procedure there are chances of large amount of blood loss which can be replaced by crystalloids and colloids like $0.9 \%$ normal saline, Ringer's lacatate, albumin and dextrose solutions and hence blood volume and haemodynamic status can be retained in such patients. Need for blood transfusions is usually seen in patients when the amount of blood loss exceeds more than $20 \%$ to $25 \%$. . $^{5}$

Whole blood is mainly used for red cell replacement with hypovolemia in acute blood loss and exchange transfusions. Packed red blood cells along with crystalloids and colloid solutions are used in patients with anemia to replace the red cells.

Blood transfusion carries major risk of transmissible infections such as HIV virus, hepatitis B,C,D, syphilis, malaria etc ${ }^{7}$

Blood is one of the most valuable resources in the living world now with limited shelf life and with considerable processing cost hence conservation of blood is important in all forms of surgery. ${ }^{8}$

\section{Tranexamic acid}

Tranexamic acid is a synthetic lysine amino acid derivative that binds to lysine binding sites of plasmin and plasminogen. It has been used to reduce blood loss during surgery, improve quality of surgical field, bloodless field surgery and also reduce need for blood tranfusions post operatively. It is available in $5 \mathrm{ml}$ ampoules containing $100 \mathrm{mg} / \mathrm{ml}$. Its mechanism of action involves saturation of the binding sites which causes separation of plasminogen from superficial fibrin and hence its prevents fibrinolysis. ${ }^{8}$

Hence, the main of the present study was to evaluate the effect of intravenous TA on perioperative blood loss during orthognathic surgery in adult patients. Also to study and assess the blood loss during surgery and the changes in hemoglobin and hematocrit in the both groups before and after surgery.

\section{Subjects and Methods}

This is aprospective, randomized, double blind, control study done in K. S. Hegde Medical Academy, Deralakattefrom January 2016 to August 2017. Patients were divided into two groups;

Group A - 52 patients receiving intravenous TA $20 \mathrm{mg} / \mathrm{kg}, 15 \mathrm{mins}$ before surgical incision

Group B- 52 patients received equal amount of NS $15 \mathrm{mis}$ before surgical incision.

\section{Inclusion criteria}

- ASA-I and ASA-II patients undergoing orthognathic surgery

- Age between 18 to 45 years

\section{Exclusion criteria}

- Patient refusal

- Allergy to the study drug

- Pregnancy

- Patients with coagulation abnormalities

- Difficult airway

After institutional ethical committee clearance, patients satisfying the inclusion criteria were enrolled in the study and informed written consent was obtained. All patients were thoroughly evaluated during pre anesthetic check up, they 
were randomly allocated into two groups using closed envelop method. All patients were kept nil per oral as per standard ASA guidelines and premedicated with Tab. Ranitidine 150mg and Tab diazepam $(5 \mathrm{mg}$ for $<50 \mathrm{~kg}$ body weight and $10 \mathrm{mg}$ for $>50 \mathrm{~kg}$ body weight) HS on previous day of surgery and 2 hours prior to the surgery. Patient was shifted to pre anesthetic ward. After confirming the identity, consent and NPO status, patient was shifted to operation theatre. Electrocardiography (ECG), pulse oximeter and non-invasive blood pressure (NIBP) monitors were attached. Baseline vitals were noted. Intravenous access was secured.

104 patients were allocated into two groups by using closed envelope method. Group A - 52 patients received intravenous TA $20 \mathrm{mg} / \mathrm{kg}$, over $15 \mathrm{~min}$ before surgical incision. Group B - 52 patients received equal amount of NS $15 \mathrm{~min}$ before surgical incision. After adequate pre oxygenation with $100 \%$ oxygen for $3 \mathrm{~min}$, analgesia was achieved with Inj. fentanyl $2 \mu \mathrm{g} / \mathrm{kg}$ body weight and patient induced with Inj. propofol $2 \mathrm{mg} / \mathrm{kg}$ body weight. After adequate bag and mask ventilation, muscle relaxation achieved with Inj. Vecuronium $0.1 \mathrm{mg} / \mathrm{kg}$ body weight.
Nasotracheal intubation was performed with appropriate sized endotracheal tube. Tube was fixed and connected to ventilator after confirming bilateral equal air entry. Anaesthesia was maintained with oxygen: nitrous oxide and isoflurane with positive pressure ventilation.

Adjuvant drugs were administered as decided and as required by the concerned anesthesiologist to maintain systolic BP $80 \mathrm{mmHg}$ to $90 \mathrm{mmHg}$ and mean arterial BP $60 \mathrm{mmHg}$ to $70 \mathrm{mmHg}$.Systolic blood pressure (SBP), Diastolic blood pressure (DBP), Mean arterial pressure (MAP), arterial blood pressure were monitored every 3 minutes throughout the procedure. Blood loss was assessed by counting the number of mops and gauzes, weighing them pre operatively and immediately after use and calculated the difference in grams (I gram $=1 \mathrm{ml}$ ). The total amount of blood in the suction was calculated by subtracting amount of irrigation fluid used throughout the procedure. Hemoglobin and hematocrit was assessed preoperatively, intraoperatively 2 hours after incision, post operatively at 6 hours and 24 hours. Patients were transfused with $\mathrm{PRBC}$ if $\mathrm{Hb}<8 \mathrm{~g} / \mathrm{dl}$ or if blood loss exceeded more than allowable blood loss.

\section{Blood loss assessment}

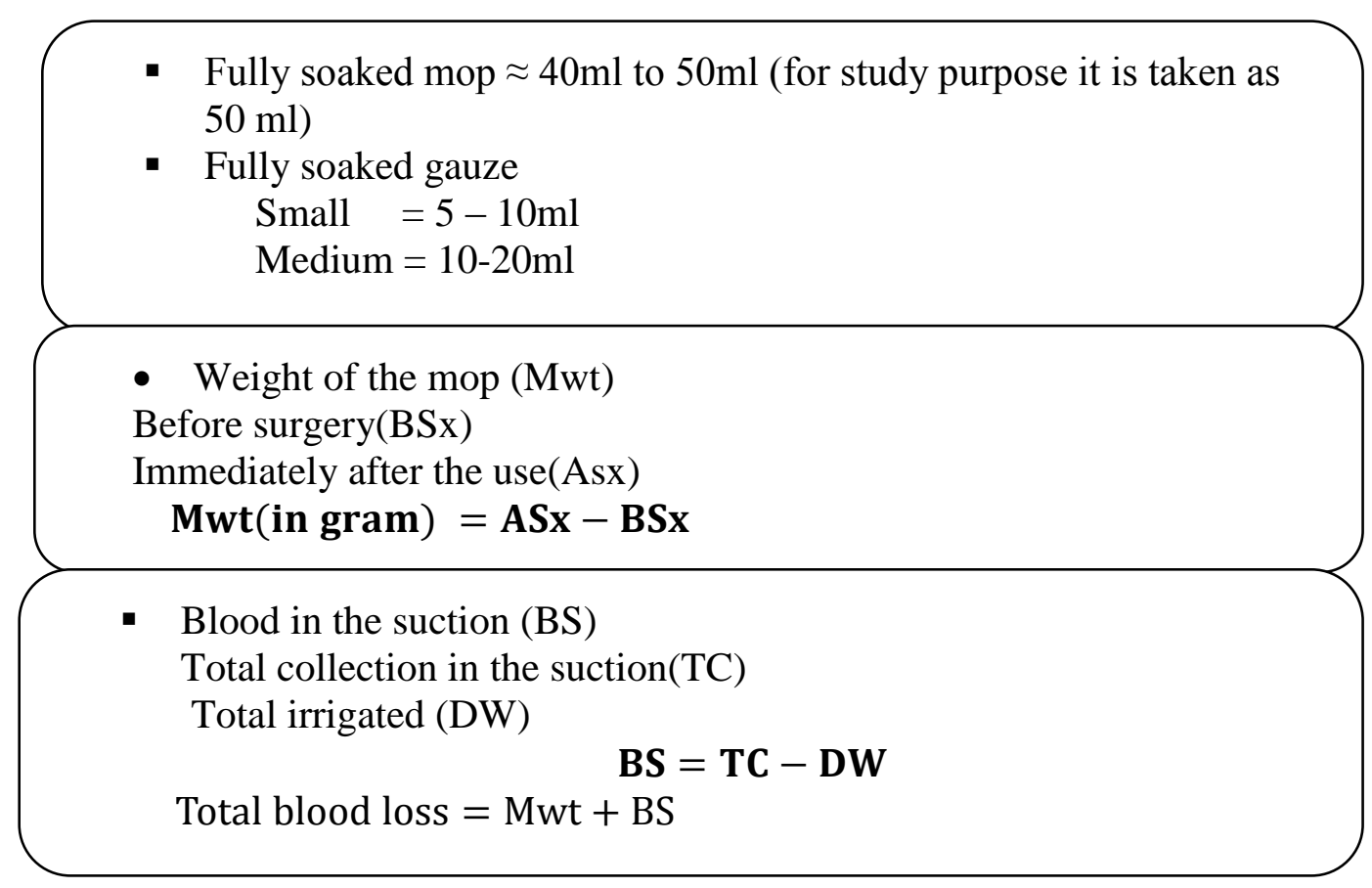




\section{Statistical Analysis}

95\% confidence interval, $80 \%$ power of the study with the difference of $300 \mathrm{ml}$ of blood loss among $900 \mathrm{ml}$ blood loss. Sample size calculated as 52 in each group by using Epi data software with the difference of $60-90 \%$.

Collected data was analyzed by both descriptive and inferential statistical methods. Data was summarized for possible assessment by frequency percentage mean and standard deviation. To compare between two groups with respective and various quantitative parameters independent $t$ test was used. To compare between groups for categorical data chi-square and Fisher exact test calculator was used. Data analysis carried out by SPSS software version 15.0.

\section{Results}

This prospective study was conducted in 104 patients. Among them, 52 received TA and 52 received placebo.

The gender distribution consisted of 23 (44.2\%) females and $29(55.8 \%)$ males in the study group and $28(53.8 \%)$ females and $24(46.2 \%)$ males in the control group (Figure 3.1).

Figure 1 Bar diagram of gender distribution in group A and group B

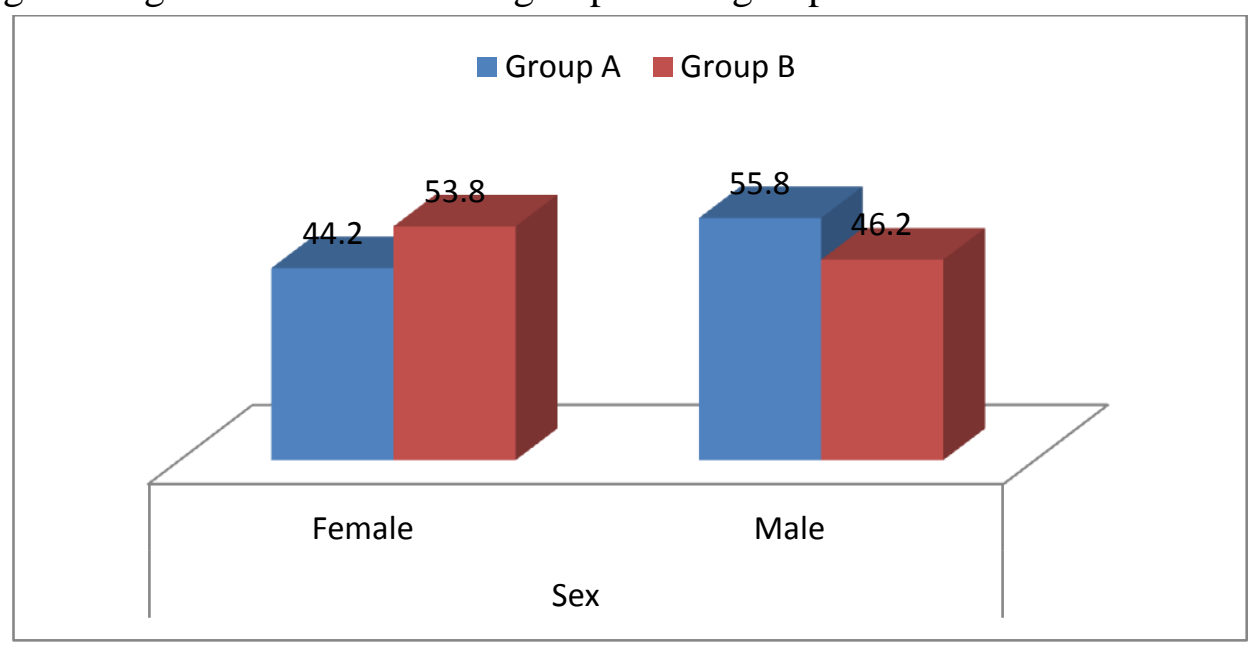

Figure 2 Bar diagram of age distribution in group A and group B

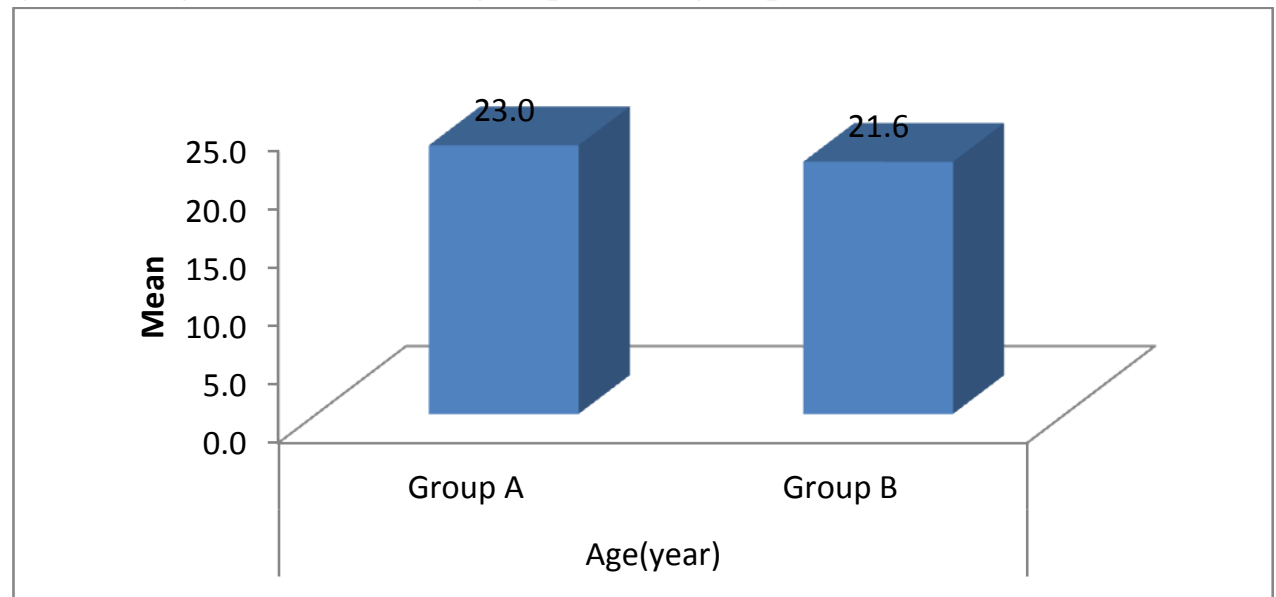

\section{Age (years)}

The age of the study group ranged from 18 years to 31 years of age (Table 2). The mean age in the study group was 23 and control group was 21.60 with no statistical significance $(p=0.106)$. (Figure 2) (Table 1). 
Table 1 Comparison of age between group A and group B Age (year)

\begin{tabular}{|c|c|c|c|c|c|}
\hline Group A & 52 & 23.00 & 3.76 & .106 & NS \\
Group B & 52 & 21.60 & 3.79 & & \\
Total & 104 & 22.30 & 3.82 & & \\
\hline
\end{tabular}

Table 2 Comparison of ASA I AND ASA II in group A and group B

\begin{tabular}{|ll|r|r|r|}
\hline & & \multicolumn{2}{|c|}{ Group: } & \multirow{2}{*}{} \\
\cline { 3 - 4 } & & Group A & \multicolumn{1}{c|}{ Group B } & \multicolumn{1}{c|}{ Total } \\
\hline ASA & 1 & 42 & 47 & 89 \\
PS: & & $80.8 \%$ & $90.4 \%$ & $85.6 \%$ \\
\cline { 2 - 5 } & 2 & 10 & 5 & 15 \\
& & $19.2 \%$ & $9.6 \%$ & $14.4 \%$ \\
\hline Total & 52 & 52 & 104 \\
& & $100.0 \%$ & $100.0 \%$ & $100.0 \%$ \\
\hline
\end{tabular}

The study and control group showed no statistical significance among the ASA I and II (X2=1.948, $\mathrm{p}=.163)$ as shown in Table 2

Table 3 Mean and standard deviation of weight of patients in group A and group B

\begin{tabular}{|l|c|c|c|c|c|}
\hline & $\mathrm{N}$ & Mean $(\mathrm{kg})$ & Std. Deviation & $\mathrm{t}$ value & $\mathrm{p}$ value \\
\hline Group A & 52 & 59.02 & 6.93 & .816 & .268 \\
\hline Group B & 52 & 57.42 & 7.68 & & $\mathrm{NS}$ \\
\hline
\end{tabular}

When weight was compared between the groups there was no statistical significance as shown in Table 3

Table 4 Comparison in duration of surgery between group A and group B

$\mathrm{N}$ - number of patients

\begin{tabular}{|l|c|c|c|c|c|c|c|}
\hline & \multirow{2}{*}{$\mathrm{N}$} & \multirow{2}{*}{ Mean (min) } & \multirow{2}{*}{ Std. Deviation } & \multicolumn{2}{|c|}{ 95\% Confidence Interval for Mean } & \multirow{2}{*}{ t value } & \multirow{2}{*}{$\mathrm{p}$ value } \\
\cline { 5 - 7 } & & & & Lower Bound & Upper Bound & & \\
\hline Group A & 52 & 176.92 & 24.93 & 169.98 & 183.86 & 2.556 & .011 \\
\hline Group B & 52 & 162.88 & 20.76 & 154.32 & 171.45 & & sig \\
\hline
\end{tabular}

There was no statistically significant difference in patient parameters like age, sex, weight and ASA classification between study and control groups. The mean duration of the study and control group was $176.92 \pm 24.93$ and $162.88 \pm 30.76$ minutes respectively. The difference in duration of the surgery had statistical significance while comparing the two groups $(p=0.02)$ as shown in Table 4

The difference in estimated blood loss in the study was statistically significant between study and control group $(p<0.001)$. The mean blood loss in study group was $280.88 \pm 59.64 \mathrm{ml}$ and control group was $330.73 \pm 100.37 \mathrm{ml}$ (figure 3) (Table 5). 


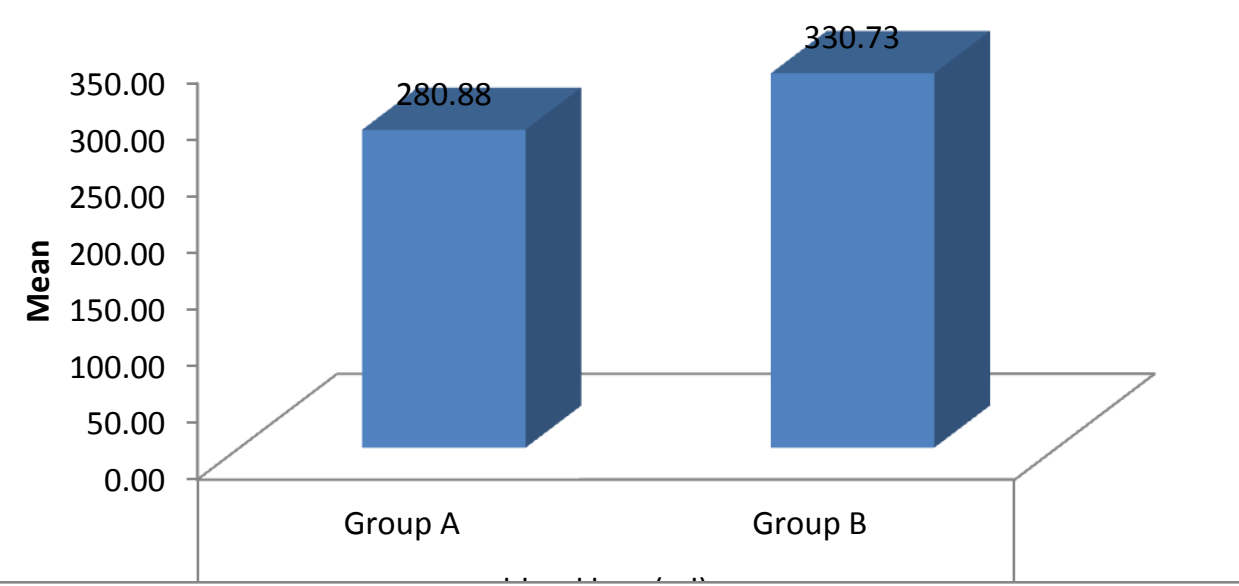

Figure 3 Bar diagram of blood loss in group A and group B

Table 5 Comparison of blood loss in group A and group B (ml)

\begin{tabular}{|l|c|c|c|c|c|c|c|}
\hline & \multirow{2}{*}{$\mathrm{N}$} & \multirow{2}{*}{ Mean } & \multirow{2}{*}{ Std. Deviation } & \multicolumn{2}{|c|}{$95 \%$ Confidence Interval for Mean } & \multirow{2}{*}{$\mathrm{t}$ test value } & $\mathrm{p}$ value \\
\cline { 5 - 6 } & & & Lower Bound & Upper Bound & & \\
\hline Group A & 52 & 280.88 & 59.64 & 264.28 & 297.49 & 3.079 & .002 \\
\hline Group B & 52 & 330.73 & 100.37 & 302.79 & 358.67 & & $\mathrm{HS}$ \\
\hline
\end{tabular}

Table 6 Comparison of peri-operative $\mathrm{Hb}$ in group A and group B

\begin{tabular}{|c|c|c|c|c|c|c|c|c|}
\hline & & \multirow[b]{2}{*}{$\mathrm{N}$} & \multirow[b]{2}{*}{ Mean } & \multirow[b]{2}{*}{$\begin{array}{c}\text { Std. } \\
\text { Deviation }\end{array}$} & \multicolumn{2}{|c|}{$\begin{array}{l}95 \% \text { Confidence Interval } \\
\text { for Mean }\end{array}$} & \multirow{2}{*}{$\begin{array}{c}\text { Repeated } \\
\text { messures } \\
\text { ANOVA F } \\
\text { value }\end{array}$} & \multirow[b]{2}{*}{$\mathrm{p}$ value } \\
\hline & & & & & $\begin{array}{l}\text { Low er } \\
\text { Bound }\end{array}$ & $\begin{array}{l}\text { Upper } \\
\text { Bound }\end{array}$ & & \\
\hline \multirow[t]{4}{*}{ Group A } & Pre op & 52 & 13.45 & 1.46 & 13.04 & 13.86 & 200.566 & \multirow[t]{4}{*}{.000} \\
\hline & $2 \mathrm{~h}$ after incision & 52 & 12.95 & 1.35 & 12.58 & 13.33 & & \\
\hline & Post op after $6 \mathrm{~h}$ & 52 & 12.06 & 1.29 & 11.70 & 12.42 & & \\
\hline & Post op after $24 \mathrm{~h}$ & 52 & 11.83 & 1.30 & 11.46 & 12.19 & & \\
\hline \multirow[t]{4}{*}{ Group B } & Pre op & 52 & 13.39 & 1.20 & 13.05 & 13.72 & 287.984 & \multirow{4}{*}{ HS } \\
\hline & $2 \mathrm{~h}$ after incision & 52 & 12.87 & 1.11 & 12.56 & 13.18 & & \\
\hline & Post op after $6 \mathrm{~h}$ & 52 & 11.44 & .84 & 11.20 & 11.67 & & \\
\hline & Post op after $24 \mathrm{~h}$ & 52 & 10.93 & .87 & 10.68 & 11.17 & & \\
\hline
\end{tabular}

Figure 4 Bar diagram of peri-operative $\mathrm{Hb}$ in group A and group B

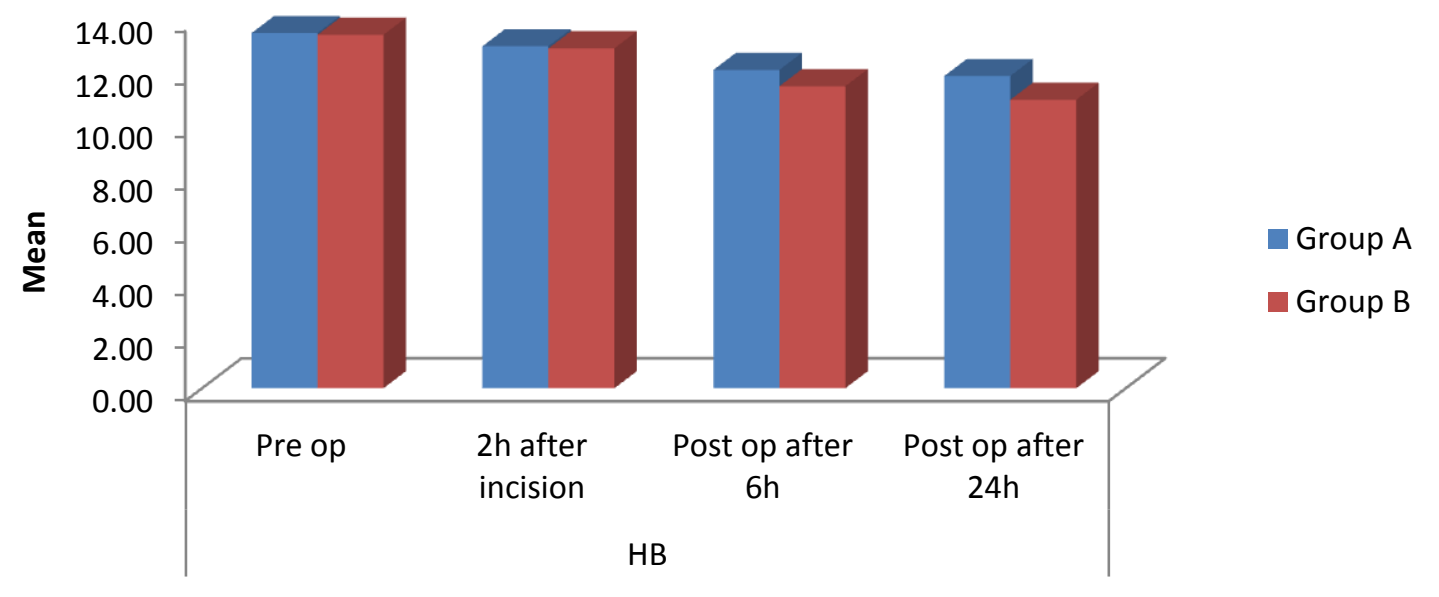


The mean pre op $\mathrm{Hb}(\mathrm{g} \%)$ in the study and control group was $13.45 \pm 1.46 \%$ and $13.39 \pm 1.2 \%$ respectively. $\mathrm{Hb} 2$ hours after incision was $12.95 \pm 1.35 \%$ in the study group and $12.87 \pm 1.11 \%$ in the control group. Post op Hb after 6 hours and
24 hours in the study group was $12.06 \pm 1.29 \%$ and $11.83 \pm 1.30 \%$ respectively. In control group post op $\mathrm{Hb}$ after 6 hours and 24 hours was $11.44 \pm .84 \%$ and $10.93 \pm 0.87 \%$ respectively.

Table 7 Comparison of perioperative Hct in group A and group B

\begin{tabular}{|c|c|c|c|c|c|c|c|c|}
\hline & & \multirow[b]{2}{*}{$\mathrm{N}$} & \multirow[b]{2}{*}{ Mean } & \multirow[b]{2}{*}{$\begin{array}{l}\text { Std. } \\
\text { Deviation }\end{array}$} & \multicolumn{2}{|c|}{$\begin{array}{l}95 \% \text { Confidence Interval } \\
\text { for Mean }\end{array}$} & \multirow[b]{2}{*}{ t value } & \multirow[b]{2}{*}{$p$ value } \\
\hline & & & & & $\begin{array}{l}\text { Lower } \\
\text { Bound }\end{array}$ & $\begin{array}{l}\text { Upper } \\
\text { Bound }\end{array}$ & & \\
\hline \multirow[t]{2}{*}{ Pre op } & Group A & 52 & 40.51 & 4.34 & 39.30 & 41.71 & \multirow[t]{2}{*}{.28} & \multirow[t]{2}{*}{.781} \\
\hline & Group B & 52 & 40.29 & 3.52 & 39.31 & 41.27 & & \\
\hline \multirow[t]{2}{*}{$2 \mathrm{~h}$ after incision } & Group A & 52 & 38.94 & 4.06 & 37.81 & 40.07 & \multirow[t]{2}{*}{.38} & \multirow[t]{2}{*}{.705} \\
\hline & Group B & 52 & 38.66 & 3.39 & 37.72 & 39.60 & & \\
\hline \multirow[t]{2}{*}{ Post op after $6 \mathrm{~h}$} & Group A & 52 & 36.21 & 3.89 & 35.13 & 37.29 & \multirow[t]{2}{*}{2.79} & \multirow[t]{2}{*}{.006} \\
\hline & Group B & 52 & 34.39 & 2.63 & 33.66 & 35.12 & & \\
\hline \multirow[t]{2}{*}{ Post op after $24 \mathrm{~h}$} & Group A & 52 & 35.52 & 3.86 & 34.45 & 36.60 & \multirow[t]{2}{*}{4.03} & \multirow[t]{2}{*}{.000} \\
\hline & Group B & 52 & 32.92 & 2.62 & 32.19 & 33.64 & & \\
\hline
\end{tabular}

Figure 5 Bar diagram of peri-operative Hct in group A and group B

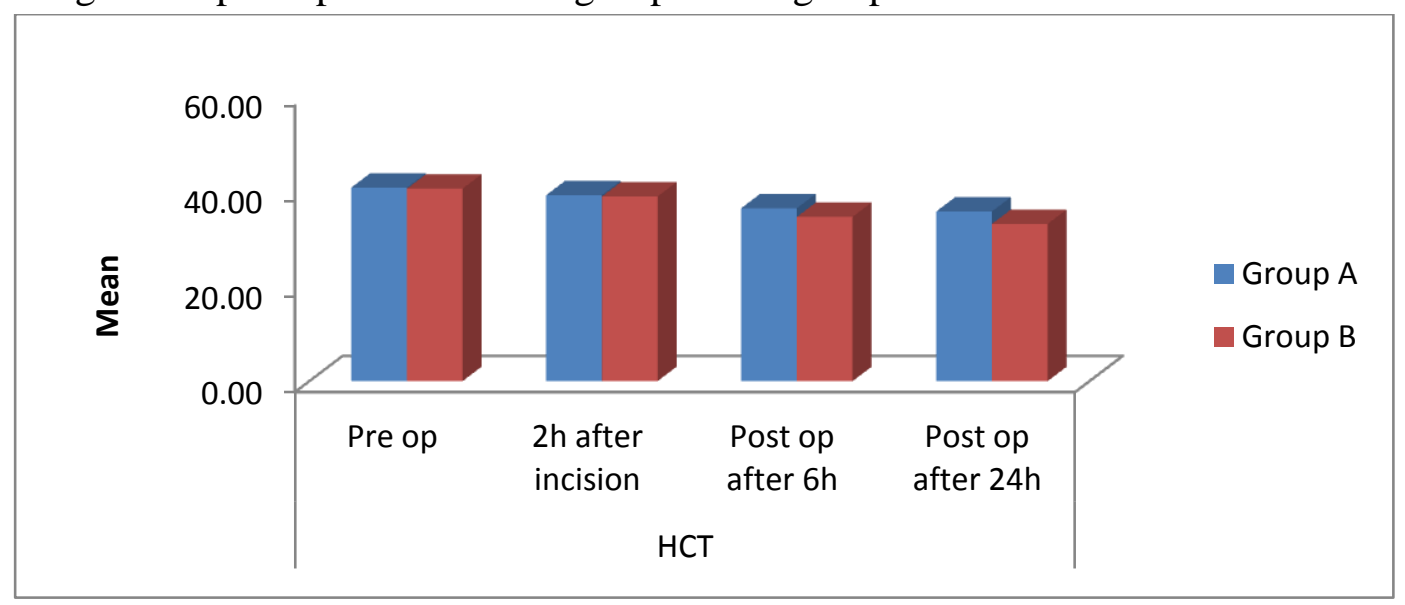

$(\%)$

The mean pre op Hct (\%) in the study and control group was $40.51 \pm 4.34 \%$ and $40.29 \pm 3.52 \%$ respectively. Hct 2 hours after incision was $38.94 \pm 4.06 \%$ in the study group and $38.66 \pm 3.39 \%$ in the control group. Postoperative $\mathrm{Hb}$ after 6 hours and 24 hours in the study group was $36.21 \pm 3.89 \%$ and $35.52 \pm 3.86 \%$ respectively. In control group postoperative $\mathrm{Hb}$ after 6 hours and 24 hours was $34.39 \pm 2.63 \%$ and $32.92 \pm 2.62 \%$ respectively.

\section{Discussion}

Minimizing blood loss during orthognathic surgery reduces the need for blood transfusion and thus the risk of complications associated with transfusion also is reduced. Use of pharmacological agents to reduce blood loss is relatively recent and TA is the most commonly used, because of its effectiveness and safety profile.

We hypothesized that TA will reduce the overall blood loss in orthognathic surgeries and hence the need for blood transfusion will be reduced. In this prospective randomized study, we administered TA $20 \mathrm{mg} / \mathrm{kg}$ as infusion over $15 \mathrm{~min}$ before surgical incision.

\section{Effect on blood loss}

There was a clinically and statistically significant reduction in the blood loss in the study group when compared to control group. Average blood 
loss during the surgery was calculated and compared between two groups. We observed there is a significant reductionin perioperative blood loss in TA group. In our study mean blood loss was $280.88 \mathrm{ml}$ in study group and $330.73 \mathrm{ml}$ in control group.

Karimi et al conducted a similar study with the same dose of TA in elective bimaxillary osteotomy in 32 patients out of which 16 received intravenous TA before induction of general anaesthesia. Hypotensive anaesthesia was their study protocol, they had used hypotensive anaesthesia by changing isoflurane concentration and by infusing 0.15 to $0.5 \mu \mathrm{g} / \mathrm{kg} / \mathrm{h}$ remifentanil ${ }^{4}$. They had used $20 \mathrm{mg} / \mathrm{kg}$ of TA and observed there is significant reduction in blood loss was observed in study group when compared to control group with a mean value of $750 \mathrm{ml}$ in control group and 585.9 in study group. In our study the measured blood loss was $280.88 \mathrm{ml}$ on study group and $330.73 \mathrm{ml}$ in control group markedly less observed in their study.

In a similar study Sankar et al evaluated the effect of TA on blood loss during orthognathic surgery with a dose of $10 \mathrm{mg} / \mathrm{kg}$ TA over a period of $20 \mathrm{~min}$ before skin incision followed by $1 \mathrm{mg} / \mathrm{kg} / \mathrm{h}$ as IV infusion till the end of the surgery. ${ }^{8}$ They used titrated dose of IV nitroglycerin to keep MAP in the rage of $70-75 \mathrm{mmHg}$ for hypotension. The mean blood loss in the study group was $166.1 \mathrm{ml}$ in contrast to $256.4 \mathrm{ml}$ in control group, there is a significant reduction in the blood loss in the study group. They concluded that use of TA along with hypotensive anaesthesia gaves better outcome in reducing blood loss in orthognathic surgery compared to hypotensive ananesthesia alone. Their study also proved that intravenous TA helps in reducing blood loss in orthognathic surgery. Corresponding values for blood loss in study and control group Sankar et al are higher.

In yet another study on blood loss in orthognathic surgery Zellin et al compared hypotensive anaesthesia alone (produced with intermittent dose of labetolol) and $1 \mathrm{~g}$ TA along with hypotension.
There is another study by Zellin et al, to evaluate blood loss in orthognathic surgery. Conducted a study in 30 patients out of which 15 patients received only hypotensive anaesthesia (intermittent dose of labetolol $5 \mathrm{mg} / \mathrm{ml}$ ) and another 15 patients $1 \mathrm{~g}$ TA with desmopressin subcutaneously $(0.3 \mu \mathrm{g} / \mathrm{kg})$ along with hypotensive anaesthesia. Mean blood loss of the study group is $400 \mathrm{ml}$ and control group is $740 \mathrm{ml}$. This study shows significant reduction in the blood loss in the study group. But here they have used fixed dose of TA along with hypotensive anaesthesia. In this study multiple drugs used to reduce blood loss during surgery. Our study proves that TA itself can reduce blood loss without adding any specific drug for hypotention. ${ }^{9}$

Choi WS et al conducted a study to evaluate the effect of TA on blood loss in bimaxillary osteotomy. In this study they used bolus dose of intravenous TA of $20 \mathrm{mg} / \mathrm{kg}$ as a bolus dose just before the surgery. In study group blood loss was around $428 \mathrm{ml}$ and in control group $643.8 \mathrm{ml}$ were the blood loss. There is a significant reduction in the blood loss in study group when comparing to study group. Hence this study also proven the effect of TA on blood loss during orthognathic surgeries. ${ }^{10}$

\section{Effect on Hemoglobin and Hematocrit}

The intravenous TA significantly reduces perioperative blood loss in orthognathic surgery simultaneously it also showed that post operative $\mathrm{Hb}$ and Hct fall is less in study group when compared to control group. In this study we also investigated $\mathrm{Hb}$ and Hct intra operatively (2h after incision) and post operatively after $6 \mathrm{~h}$ and $24 \mathrm{~h}$.

The mean preoperative $\mathrm{Hb}(\mathrm{g} \%)$ in the study and control group was $13.45 \mathrm{~g} \%$ and $13.39 \mathrm{~g} \%$ respectively. $\mathrm{Hb} 2$ hours after incision was $12.95 \mathrm{~g} \%$ in the study group and $12.87 \mathrm{~g} \%$ in the control group. Postoperative $\mathrm{Hb}$ after 6 hours and 24 hours in the study group was $12.06 \mathrm{~g} \%$ and $11.83 \mathrm{~g} \%$ respectively. In control group post op $\mathrm{Hb}$ after 6 hours and 24 hours was $11.44 \mathrm{~g} \%$ and $10.93 \mathrm{~g} \%$ respectively. 
The mean preoperative Hct (\%) in the study and control group was $40.51 \%$ and $40.29 \%$ respectively. Hct2 after hours of incision was $38.94 \%$ in the study group and $38.66 \%$ in the control group. Postoperative $\mathrm{Hb}$ after 6 hours and 24 hours in the study group was $36.21 \%$ and $35.52 \%$ respectively. In control group postoperative $\mathrm{Hb}$ after 6 hours and 24 hours was $34.39 \%$ and $32.92 \%$ respectively.

This perioperative $\mathrm{Hb}$ and $\mathrm{Hct}$ value are statistically and clinically significant, it proves the effect of intravenous TA in orthognathic surgery. There are several studies shows the similar results. In a similar study Karimiet al evaluated the efficacy of TA in elective bimaxillary osteotomy in 32 patients out of which 16 patients received same dose of TA $20 \mathrm{mg} / \mathrm{kg}$ before induction of general anesthesia. Post operatively they observed mean preoperative $\mathrm{Hb}$ were dropped from $14.11 \mathrm{~g} \%$ to $11.56 \mathrm{~g} \%$ at $1^{\text {st }}$ hour and $11.8 \mathrm{~g} \%$ in $6^{\text {th }}$ hour in TA group. In control group $\mathrm{Hb}$ were dropped from $13.7 \mathrm{~g} \%$ to $10.68 \mathrm{~g} \%$ at $1^{\text {st }}$ hour and 10.84 at $6^{\text {th }}$ hour which is statistically significant and it shows the effect of TA on Hb. In this study preoperative mean Hct in TA group were $41.46 \%$ and postoperatively it is dropped to $34.03 \%$ at $1^{\text {st }}$ hour and $34.93 \%$ in $6^{\text {th }}$ hour respectively. In control group preoperative Hct were dropped from $40.67 \%$ to $32.06 \%$ at $1^{\text {st }}$ hour and $33 \%$ at $6^{\text {th }}$ hour. So this study also agrees that $\mathrm{Hb}$ and Hct drop in TA group is always less when compared to control group. 4

There is a similar study conducted by Choi et al to evaluate to effect of intravenous TA during bimaxillary osteotomy. They also administered intravenous TA $20 \mathrm{mg} / \mathrm{kg}$ as a bolus dose before starting the surgery. In TA group mean preoperative $\mathrm{Hb}$ and $\mathrm{Hct}$ were $13.5 \mathrm{~g} \%$ and $39.6 \%$, postoperatively at $48^{\text {th }}$ hour it was $11.0 \mathrm{~g} \%$ and $32.2 \%$ respectively. In control group mean preoperative $\mathrm{Hb}$ and $\mathrm{Hct}$ were $13.8 \mathrm{~g} \%$ and $40.3 \%$, postoperatively at $48^{\text {th }}$ hour it was $10.2 \mathrm{~g} \%$ and $29.7 \%$ respectively. This study shows a significant reduction in drop in $\mathrm{Hb}$ and Hct in TA group. Hence this study also concluded that intravenous
TA before surgery significantly reducing blood loss and need for blood transfusion.

\section{Blood transfusion}

There was no necessity of blood transfusion among any patients in both the groups in spite of being a greater blood loss in the control group. This is because of the adequate pre operavite $\mathrm{Hb}$ effect and mandatory technique to keep an adequate hypotencive anaesthesia which is a part of departmental policy for maxillo facial surgeries lastly, blood loss in all patients though relatively higher in control group, was within the maximum allowable limit.

\section{Conclusion}

In our study we found that intravenous tranexamic acid significantly reduced the amount of blood loss in the study group when compared to the control group. The reduction in $\mathrm{Hb}$ and Hct levels was also less in the study group, reflecting the reduced blood loss. There was no necessity of blood transfusion in either group.

Based on our study, we conclude intravenous tranexamic acid $20 \mathrm{mg} / \mathrm{kg} 15 \mathrm{~min}$ before surgical incision is safe and effective in reducing the surgical blood loss and there by reduces the need of blood transfusion.

\section{References}

1. Koster H. Spinal anaesthesia with special reference to its use in surgeryof the head, neck and thorax. Am J Surg1928; 5 : 554

2. Al-Sebaei MO. Predictors of intraopeartive blood loss and blood trasfusion in orthognathic surgery: a retrospective cohort study in 92 patients. Patient Saf Surg. 2014; 2;8(1):41.

3. Rummask D, Apipan B, Kaepradup P: Factors that determine intraoperative blood loss in bimaxillary osteotomies and the need for preoperative blood preparation. $\mathbf{J}$ Oral MaxillofacSurg 2011, 69(11):e456-60

4. Karimi A, Soltani S, Hasheminaseb M. Efficacy of tranexamic acid on blood loss during bimaxilary osteotomy: A 
randomized double blind clinical trial.

Saudi J. Anesth. 2012;6(1):41-45.

5. Rodrigo C. Induced hypotension during anesthesia, with special reference to orthognathic surgery. Anesh Prog.1995; 42:41-58.

6. Faverani LP, Ramalho-Ferreira G, Fabris AL, Polo TO, Poli GH, Pastori CM, Marzola C: Assuncao WG. Intraoperative blood loss and blood transfusion requirements in patients undergoing orthognathic surgery. Oral and maxillofacial surgery: Garcia-junior IR;2013

7. The Clinical Use of Blood Handbook. World health organization; blood transfusion safety. Page no.165.

8. Sankar D, Krishnan R, Veerabahu M, Vikraman B. Evaluation of the efficacy of tranexamic acid on blood loss in orthognathic surgery. A prospective, randomized clinical study. Int. J. Oral Maxillofac. Surg. 2012;41(6):713-17.

9. Zellin G, Rasmusson L, Pålsson J, Kahnberg E. Evaluation of hemorrhage depressors on blood loss during orthognathic surgery: a retrospective study. J. Oral Maxillofac. Surg. 2004;62(6):662-666.

10. Choi WS, Irwin MG, Samman N. The effect of tranexamic acid on blood lossduringorthognathic surgery: A randomized controlled trial. J. Oral Maxillofac. Surg. 2009;67(1):125-133. 